\title{
Improved model for the non-destructive estimation of strawberry leaf area
}

Hüsnü DemırsoY*, Leyla Demırsoy, Ahmet ÖztürK

Ondokuz Mays University, Faculty of Agriculture, Department of Horticulture, 55139 Kurupelit-Samsun, Turkey

husnud@omu.edu.tr
${ }^{*}$ Correspondence and reprints

Fruits, 2005, vol. 60, p. 69-73 (C) 2005 Cirad/EDP Sciences All rights reserved

DOI: $10.1051 /$ fruits:2005014

RESUMEN EsPaÑoL, p. 73

\section{Improved model for the non-destructive estimation of strawberry leaf area.}

Abstract - Introduction. Non-destructive estimation of leaf area saves time as compared with geometric measurements. For this reason, several leaf area prediction models were produced for some plant species such as grape, avocado and kiwifruit in previous studies. In this research, we attempted to offer a reliable equation that predicts strawberry leaf area non-destructively by linear measurements of leaf geometry. Materials and methods. An equation was developed by using Sweet Charlie and Camarosa strawberry cultivars and by measuring lamina width, length and leaf area. Results and discussion. It was found that the relationships between the actual leaf area and the predicted leaf area given by the equation developed were significant at a level of $0.1 \%$ and that $r^{2}$ was 0.993 . In addition, the model was validated by measurements of new leaf areas of seven other strawberry cultivars. Conclusions. The model developed could be used for strawberries in relevant studies.

Turkey / Fragaria / leaf area index / methods / evaluation / mathematical models

\section{Modèle amélioré pour une évaluation non destructive de la surface d'une feuille de fraisier.}

Résumé - Introduction. L'évaluation non destructive de la surface d'une feuille est plus rapide que l'utilisation de mesures géométriques. Pour cette raison, diverses études ont proposé des modèles permettant de prévoir la surface des feuilles pour des espèces végétales comme le raisin, l'avocat et le kiwi. Nos recherches ont tenté d'établir une équation fiable apte à évaluer la surface des feuilles de fraisiers à partir d'une méthode non destructive s'appuyant sur des mesures linéaires de la feuille. Matériel et méthodes. Une équation a été développée à partir de l'utilisation des cultivars de fraisiers Sweet Charlie et Camarosa en mesurant la largeur, la longueur et la surface des feuilles. Résultats et discussion. On a constaté que la différence entre la surface réelle de la feuille et sa surface théorique donnée par l'équation mise au point étaient significative au seuil de $0,1 \%$ et que $r^{2}$ était égal à 0,993 . En outre, le modèle a été validé par la mesure de la surface de feuilles appartenant à sept autres cultivars de fraisiers. Conclusions. Le modèle développé pourrait être utilisé pour des études appropriées sur fraisiers.

Turquie / Fragaria / indice de surface foliaire / méthode / évaluation / modèle mathématique 


\section{Introduction}

Leaf area is routinely measured in experiments interested in horticultural crops where some physiological phenomenon such as light, photosynthesis, respiration, plant water consumption or transpiration is being studied [1-7]. In addition, leaf number and area of a plant are important for cultural practices such as training, pruning, irrigation, fertilization, etc.

Leaf area estimation models that aim to predict leaf area non-destructively can provide researchers with many advantages in horticultural experiments. Moreover, these kinds of models enable researchers to carry out leaf area measurements on the same plants over the course of a study, resulting in reduced experimental variability [8-10].

Leaf area can be determined by using expensive instruments and/or predictive models. Recently, new instruments, tools and machines such as hand scanners and laser optic apparatuses have been developed for leaf and fruit measurements. These are very expensive and complex devices for basic and simple studies. Furthermore, nondestructive estimation of leaf area saves time as compared with geometric measurements [11]. For this reason, several leaf area prediction models were produced for some plant species such as grape, avocado and kiwifruit in previous studies.

Figure 1.

Diagram of a strawberry plant leaf showing the position of the measurements used to define the leaf area with a planimeter.

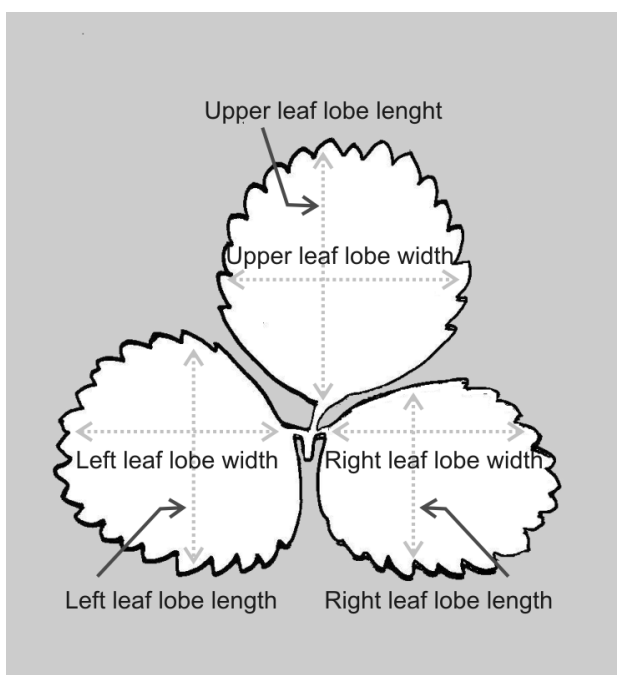

In this document, we offer a reliable equation that allows the non-destructive estimation of leaf area through linear measurements of strawberry leaves.

\section{Materials and methods}

Our study was carried out to develop a leaf area estimation model by using two strawberry cultivars: Sweet Charlie and Camarosa.

Leaf samples were randomly taken from strawberries planted in a plastic unheated greenhouse between September 2002 and March 2003 five times at intervals during this period. In the experiment, a total of 900 leaves were measured for the two cultivars: 450 leaf samples for each cultivar. Initially, each leaf was placed on an A3 sheet and copied (at a 1:1 ratio) with a photocopier. A placom digital planimeter (Sokkisha Planimeter Inc., Model KP-90) was used to measure the actual leaf area of the copy. The leaf width (W) and length (L) of the leaf samples were also measured for model construction. Leaf width $(\mathrm{cm})$ was measured from tip to tip at the widest part of the lamina and leaf length $(\mathrm{cm})$ was measured from the lamina tip to the point of petiole intersection along the midrib. All values were recorded to the nearest $0.1 \mathrm{~cm}$ and the process was repeated for each of the trifoliate leaflets (figure 1).

Multiple regression analysis of the data was performed for each cultivar separately. For this reason, analysis was conducted with various subsets of the independent variables, namely, upper lobe length (ULL) and left lobe width (LLW) to develop the best model for predicting leaf area (LA) by using the Microsoft Office XP Excel package program. The multiple regression analysis was carried out until the least sum of squares was obtained.

In addition, leaves of seven strawberry cultivars (Sweet Charlie, Camarosa, Honeoye, Annapolis, Muir, Tudla and Elvira) grown in a different region, Yalova Province, were taken to validate the model produced. For each cultivar, 40 new leaf samples were used for this aim. Leaf width, length and actual leaf area of these leaf samples were measured as mentioned in the model construction. 


\section{Results and discussion}

In the study, a leaf area model for strawberries was developed by evaluating several different linear parameters. The regression analyses with the best predictive values of leaf area were explained by the selection of parameters such as upper lobe length (ULL) and left lobe width (LLW). The variation explained by these parameters was $99.3 \%$ for the two cultivars used in the model (table I). Based upon these results, there was a highly reliable relationship between actual and predicted leaf area values (figure 2).

Validation for determining the degree of accuracy of the model was carried out by measuring actual leaf area using a placom digital planimeter and then by regressing these values against the predicted leaf areas of the seven cultivars using the parameters developed in the model (figure 3). It was found that the relationships ( $r^{2}$ values) between actual and predicted leaf areas varied from (97.30 to 98.97)\% (highest in 'Annapolis' and lowest in 'Tudla') in the model (figure 3).

Many studies carried out to establish reliable relationships between leaf area and leaf dimensions of different plant species such as avocado, lotus plum, kiwifruit, aubergine, pepper, cucumber, grape red currant species, squash, onion, pecan, rabbiteye blueberry and gooseberry [8, 9, 11-15] showed that there were close relationships between leaf width, leaf length and leaf area (for example: $r^{2}=0.983$ for avocado, lotus plum, kiwifruit, aubergine and pepper; $r^{2}=0.76$ to 0.99 for cucumber; $r^{2}=0.9841$ to 0.9844 for grapes; $r^{2}=0.986$ for red currant; $r^{2}=0.976$ to 0.986 for squash). In a model developed for strawberries, the leaf area estimation equation was found to be $y=165.91 x-$ 2716.35 or $y=161.03 x_{1}-2121.8$, where $y$ is the estimated area of the trifoliate leaf, $x$ is the width of the top leaflet and $x_{1}$ is the width of the side leaflet by Mandal et al. [16]. When applied to our data, the $r^{2}$ value of the model obtained by Mandal et al. [16] was $95.15 \%$, whereas the $r^{2}$ value of the model produced in the present study was $99.3 \%$.

Validation of a leaf area model is an important step to overcome the implications of produced equations for prediction of leaf

Table I.

Relationship between the actual strawberry leaf area and independent variables used for a non-destructive estimation with a prediction model.

\section{Prediction model} $r^{2}$

$\begin{array}{ccc}\text { Leaf area }= & 1.89+ & 2.145 \times \text { upper lobe length } \times \text { left lobe width } \\ \text { Standard error : } & 0.396^{\star \star \star} & 0.006^{\star \star \star}\end{array}$

\section{Significant at a level of $0.1 \%$}

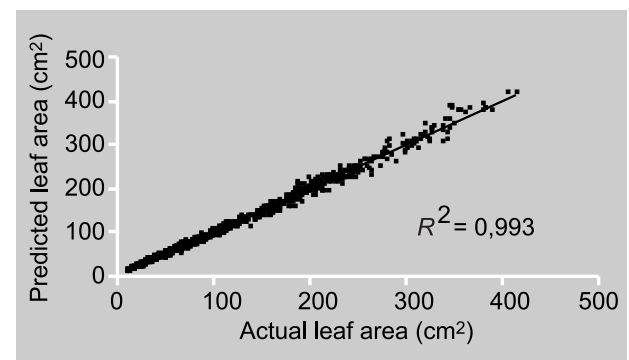

area. Confidence in the precision of these models would provide researchers with a reasonably fast and inexpensive method to use in studies on plant phenomena such as respiration, transpiration and photosynthesis without destructive leaf harvesting. Some researchers validated their own developed leaf area prediction model. Celik and Uzun [17] found that the relationships ( $r^{2}$ values) between actual and predicted leaf areas varied from 0.918 in lotus plum to 0.988 in peppers. In the validation process in the present study, it was found that the $r^{2}$ value showing the relationship between actual and predicted leaf areas was $\cong(99$ to 99$) \%$. We demonstrated the utility and reliability of our model on the same two cultivars and five additional cultivars, all grown under different environmental conditions.

\section{Conclusions}

We developed the simple model for predicting leaf area for strawberry. It was found that there were not significant differences among the cultivars with respect to any parameter
Figure 2.

The overall relationship between the measurements of the actual leaf area of strawberries and the predicted leaf area obtained from the use of the model proposed in table I $(n=900)$ 


\section{H. Demirsoy et al.}

Figure 3.

The relationships between the measurements of the actual leaf area and the predicted leaf area obtained from the use of the model proposed in table I for the seven cultivars of strawberries used $(n=40)$.

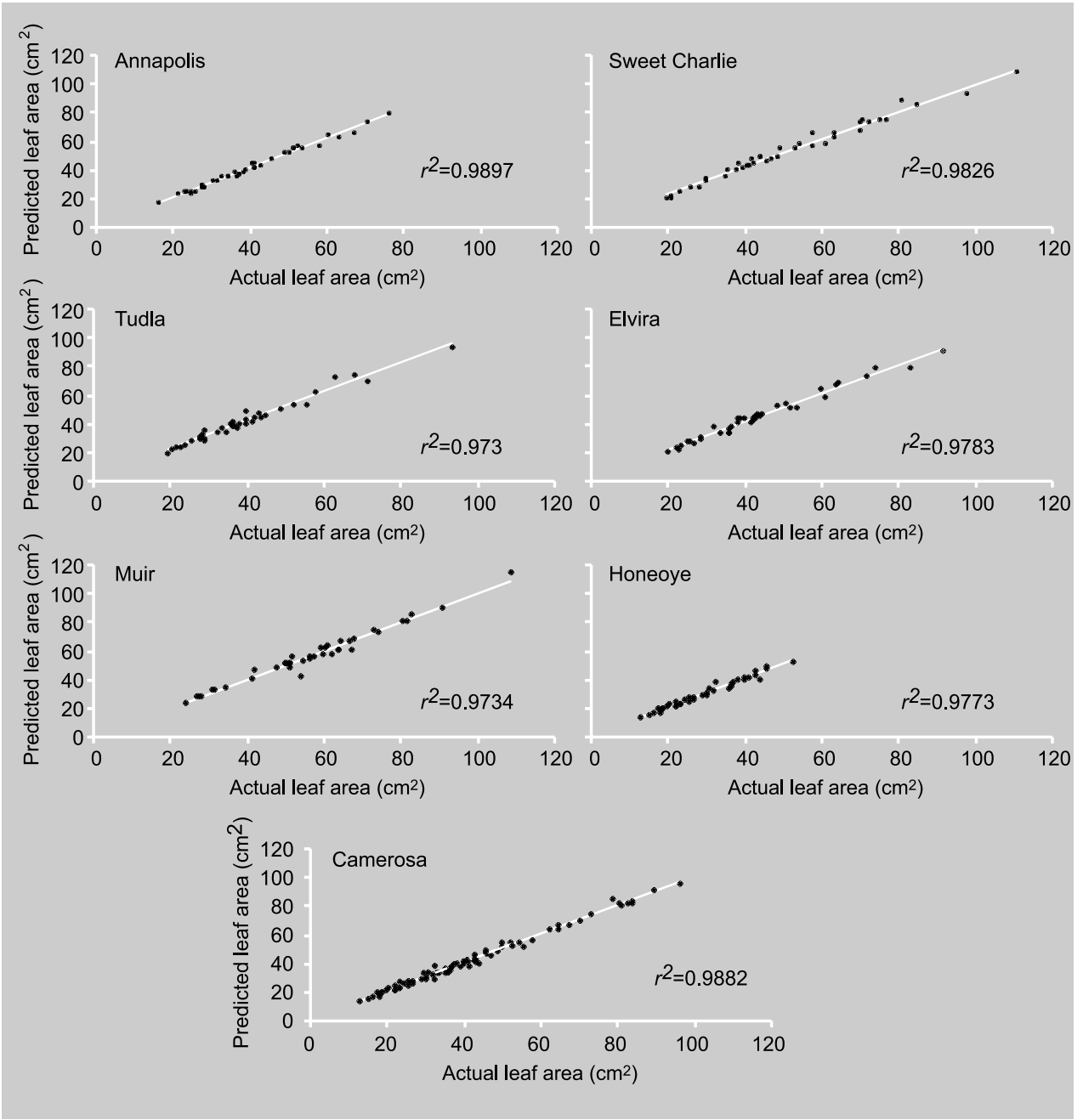

in the model. For this reason, the model could be used for the prediction of strawberry leaf area in relevant studies.

\section{References}

[1] Centritto M., Loreto F., Massacci A., Pietrini F., Villani M.C., Zacchine M., Improved growth and water use efficiency of cherry saplings under reduced light intensity, Ecol. Res. 15 (4) (2000) 385-392

[2] Gottschalk K.W., Shade, leaf growth and crown development of Quercus rubra, Quercus velutina, Prunus serotina and Acer rubrum seedlings, Tree Physiol. 14 (7-9) (1994) 735749 .
[3] Horsley S.B., Gottschalk K.W., Leaf area and net photosynthesis during development of Prunus serotina seedlings, Tree Physiol. 12 (1) (1993) 55-69.

[4] Kerstiens G., Hawes C.W., Response of growth and carbon allocation to elevated $\mathrm{CO}_{2}$ in young cherry (Prunus avium L.) saplings in relation to root environment, New Phytol.

[5] Picchioni G.A., Weinbaum, S.A., Brown P.H., Retention and the kinetics of uptake and export of foliage-applied, labeled boron by apple, pear, prune, and sweet cherry leaves, J. Am. Soc. Hortic. Sci. 120 (1) (1995) 28-35.

[6] Uzun S., The quantitative effects of temperature and light environment on the growth, 128 (4) (1994) 607-614. 
development and yield of tomato (Lycopersicon esculantum Mill.) and aubergine (Solanum melongena L.), Univ. Reading, thesis, Reading, UK, 1996, $226 \mathrm{p}$.

[7] Rieger M., Duemmel M.J., Comparison of drought resistance among Prunus species from divergent habitats, Tree Physiol. 11 (4) (1992) 369-380.

[8] Gamiely S., Randle W.M., Mills H.A., Smittle D.A., A rapid and non-destructive method for estimating leaf area of onions, HortScience 26 (2) (1991) 206.

[9] NeSmith D.S., Non-destructive leaf area estimation of rabbiteye blueberries, HortScience 26 (10) (1991)1332.

[10] NeSmith D.S., Estimating summer squash leaf area non-destructively, HortScience 27 (1) (1992) 77.

[11] Robbins N.S., Pharr, D.M., Leaf area prediction models for cucumber from linear measurements, HortScience 22 (6) (1987) 12641266.
[12] Elsner E.A., Jubb G.L. Jr., Leaf area estimation of Concord grape leaves from simple linear measurements, Am. J. Enol. Viticult. 39 (1) (1988) 95-97.

[13] Tamal S., Opadhyay A.B., Chattopadhyay T.K., Pranab G., A nondestructive way of estimating leaf area in Cape gooseberry (Physalis peruviana), Prog. Hortic. 20 (3-4) (1988) 324-325.

[14] Whitworth J.L., Mauromoustakos A., Smith M.W., A non-destructive method for estimation of leaf area in pecan, HortScience 27 (7) (1992) 851.

[15] Uzun S., Çelik H., Leaf area prediction models (uzçelik-1) for different horticultural plants, Turk J. Agric. For. 23 (1999) 645-650.

[16] Mandal K.K., Ghosh S.K., Gayen P., A nondestructive way of leaf area estimation in the strawberry, Ann. Biol. 18 (1) (2002) 19-24.

[17] Çelik H., Uzun S., Validation of leaf area estimation models (Uzçelik-1) evaluated for some horticultural plants, Pak. J. Bot. 34 (1) (2002) 41-46.

\section{Modelo mejorado para una evaluación no destructiva de la superficie de una hoja de fresal.}

Resumen - Introducción. La evaluación no destructiva de la superficie de una hoja hace ganar tiempo respecto de la utilización de medidas geométricas. Por esta razón, distintos estudios han propuesto modelos que permiten la estimación de la superficie foliar de especies vegetales como uvas, aguacates y kiwis. Nuestros estudios intentaron establecer una ecuación fiable capaz de evaluar la superficie de las hojas de fresal a partir de un método no destructivo basado en medidas lineales de la hoja. Material y métodos. Se desarrolló una ecuación a partir de la utilización de cultivares de fresas Sweet Charlie y Camarosa midiendo la longitud y la superficie foliar. Resultados y discusión. Se constató que la diferencia entre la superficie real de la hoja y su superficie teórica, expresada por la ecuación desarrollada, era significativa en el nivel del $0,1 \%$ y que $r^{2}$ era igual a 0,993 . Además, el modelo fue validado mediante la medida de la superficie foliar de otros siete cultivares de fresa. Conclusiones. El modelo desarrollado podría utilizarse para realizar estudios apropiados en fresas.

Turquía / Fragaria / indice de superficie foliar / métodos / evaluación / modelos matemáticos 